\title{
INFORMATION AVOIDANCE BEHAVIOR REGARDING HOAXES INDICATORS
}

\author{
Raymond Godwin, Fanny Chairunnisa, Rani Agias Fitri \\ Jurusan Psikologi, Fakultas Humaniora, Universitas Bina Nusantara \\ J1. Syahdan No. 9, Jakarta 11480 \\ rgodwin@binus.ac.id
}

\begin{abstract}
Hoaxes have become a common phenomenon in Indonesia. The Indonesian Telematics Society Survey shows that even though Indonesian people understand the way in recognizing hoaxes, they Indonesia are not sure of being able to immediately recognize hoaxes. Based on previous studies, there are two reasons that lead to lack of the assuredness, namely, the idleness in using thinking skills and ignorance of hoax indicators in the news they read. This study aims to find the correlation between avoidance behavior toward information that can indicate hoax, critical skill, and individual perception of easiness in obtaining the information regarding hoaxes. Information Avoidance Scale and the Critical Skill dimensions of the Digital Literacy Scale were adapted to Bahasa Indonesia to measure the tendency of information avoidance and critical skills. Whereas an instrument to measure the perception of the easiness to obtain information was constructed independently. The results indicate that critical skills and perceptions of the easiness to obtain information have a negative correlation with the tendency to avoid information. However, because the correlation is poor, critical skills and perceptions of the easiness to obtain information do not adequately explain a person's tendency to avoid information that can help him to recognize hoaxes.
\end{abstract}

Keywords: hoaxes; information avoidance; fake news; critical skills

\begin{abstract}
Abstrak
Saat ini hoax menjadi fenomena yang umum ditemui di tengah masyarakat. Masyarakat Telematika Indonesia melalui surveinya memperlihatkan bahwa masyarakat Indonesia tahu cara mengenali hoaks dan berpendapat bahwa cara itu mudah dilakukan, namun tidak yakin untuk dapat langsung mengenalinya. Berdasarkan analisis terhadap hasil penelitian-penelitian sebelumnya, peneliti melihat ada dua hal yang dapat menyebabkan ketidakyakinan masyarakat Indonesia untuk mengenali hoaks, yaitu malas menggunakan kemampuan berpikirnya dan tidak acuh terhadap indikator hoaks yang ada dalam berita yang sedang dihadapinya. Penelitian ini melihat hubungan antara penghindaran terhadap informasi yang dapat membantu untuk mengenali hoaks dengan keterampilan kritis dan persepsi individu mengenai kemudahan untuk mendapatkan informasi tersebut. Peneliti mengadaptasi Information Avoidance Scale dan dimensi critical skill dari Digital Literacy Scale untuk mengukur kecenderungan penghindaran informasi serta keterampilan kritis. Sedangkan untuk persepsi mengenai kemudahan mendapatkan informasi, alat ukur disusun secara mandiri. Hasil penelitian ini memperlihatkan bahwa keterampilan kritis maupun persepsi mengenai kemudahan mendapatkan informasi memiliki hubungan negatif dengan kecenderungan untuk menghindari informasi. Akan tetapi, kedua hubungan itu sangat rendah sehingga dapat dinyatakan bahwa keterampilan kritis dan persepsi mengenai kemudahan mendapatkan informasi tidak cukup menjelaskan kecenderungan seseorang untuk menghindari informasi yang sebenarnya dapat membantunya mengenali hoaks.
\end{abstract}

Kata kunci: hoaks; penghindaran informasi; berita bohong; keterampilan kritis

\section{INTRODUCTION}

Not less than five years hoaxes have become a common phenomenon in Indonesia. Especially during the Election for DKI Jakarta Regional Head in 2012, hoaxes were widespread. This phenomenon continues to the Presidential Election in 2014, Regional Election 2017, also at Presidential and General Election in 2019.

A survey of 1116 respondents in 2017, conducted by the Indonesian Telematics Society (Masyarakat Telematika 
Indonesia/Mastel, 2017), shows that most people in Indonesia were exposed to hoaxes every day through conventional media, such as radio, television, newspaper, and digital media, for instance, websites, social media application, email. Most of the hoaxes contain issues that related to social-political and SARA (ethnicity, religion, race, and intergroup). The survey also indicates a massive circulation of hoaxes in Indonesian society.

In Bahasa Indonesia, hoaxes refer to fake news (Kamus Besar Bahasa Indonesia/KBBI Daring, 2016), that can be defined as intentionally fabricated news articles (Allcott \& Gentzkow, 2017). Fake news is either wholly false or containing deliberately misleading elements that been incorporated within its content or context (Bakir \& McStay, 2017). The misleading in the hoaxes are deliberately made, but it can be proven wrong (Allcott \& Gentzkow, 2017). Lazer et al. (2018) argue that hoaxes is a form of information disruption, both misinformation (false information) and disinformation (false information intended to deceive). The appearances of hoaxes are similar to any news (Lazer et al., 2018; Tandoc Jr., Lim, \& Ling, 2017), but the process and the organization in constructing the news, also their purposes are dissimilar (Lazer et al., 2018).

Currently, the increasing use of social media plays an important role in hoax spread (Allcott \& Gentzkow, 2017; Tandoc Jr. et al., 2017). In Indonesia, it was depicted in the Mastel survey (2017), which stated that the three most common hoax delivery channel was social media applications (92.4\%), short message applications (62.8\%), and websites $(34.9 \%)$. Considering the connectedness between social media and hoaxes, Klein and Wueller (2017) define hoax as an online news that intentionally made and also recognized as incorrect about facts. Although misinformation are often occurred in various media, the rapidity and easiness of spreading the news via social media aggravate the disadvantage of hoaxes, and it is difficult to provide corrective information to counter the hoax (Fernandez \& Alani, 2018). And it became even more concerning because Indonesians who have access to the news in online and social media, mainly aged $21-30$ years, also have a quite high level of trust from the internet (Manalu, Pradekso, \& Setyabudi, 2018). Therefore, hoaxes can reach people rapidly.

The rapid spread of hoaxes through the online or digital world, as well as rapid technology development, require individuals to use their technical, cognitive and sociological skills to deal with various issues in the digital environment (Eshet-Alkali \& Amichai-Hamburger, 2004). Those skills are outlined in terms of digital literacy (Buckingham, 2003, 2015; Hargittai, 2005), also known as media literacy (Sirajuddin, Kamil, \& Fachruddin, 2017). The various skills in digital literacy, especially information literacy skills, are essential for everyone to become a smart informationconsumer (Eshet-Alkali \& AmichaiHamburger, 2004). These skills also help someone to be able to identify the wrong, irrelevant, or biased information, and avoids the penetration of that information to his/her cognition (Eshet-Alkali \& AmichaiHamburger, 2004). Therefore, in order to be able to survive from the disadvantage of information dissemination in the technological development era, each individual should be capable in identifying and evaluating the following information correctly.

Digital literacy skills are composed of information skills and critical skills (Rodríguez-de-Dios \& Igartua, 2014). Information skills refer to the ability to find, obtain, and evaluate relevant information. Critical skills (CS) refer to the ability to analyze the obtained information and particularly identify the fact of the information. CS enable individuals to evaluate the information, but it focuses on identifying the fact, not about the term to be relevant. This critical skill is closely tied to 
the ability to recognize the fake news (Pennycook \& Rand, 2018).

Based on their research, Pennycook and Rand (2018) explain that one's ability to analyze hoaxes plays an important role in dealing with hoaxes. But, Pennycook and Rand (2018) also state that people who believed in hoaxes is not necessarily not having analytical skills. They just do not want to use it. In other words, failure to refuse hoaxes occurs because individuals do not use their analytical skills. The Mastel survey (2017) also indicating the same thing. According to Mastel (2017), Indonesian people believe that verifying the fact of information is uncomplicated, but they are not sure that they can immediately recognize whether the news that they read were hoaxes or not. Indonesian people are aware of hoax indicators, they understand the steps to be taken after got suspected hoaxes, and able to verify the fact of news, but they hesitate on that abilities. They entrust the fact confirmation to the internet and other trusted people (Mastel, 2017).

Based on the survey results conducted by Mastel (2017) and Pennycook and Rand (2018), there are two reasons or possible causes for someone fail to reject hoaxes. In the first condition, as explained by Pennycook and Rand (2018), someone fails to reject hoaxes because he just lazy to use his analytical skills. Whereas in the other condition, the person fails to reject hoaxes because he ignores or even avoids the hoax indicators in the news he reads. The avoidance might happen because he did belief the news wasn't hoax or just did not want to spend time to check.

The avoidance of hoax indicators can be seen as information avoidance behavior, which refers to any behavior intended to prevent or delay the acquisition of available but potentially unwanted information (Sweeny, Melnyk, Miller, \& Shepperd, 2010). The main reason for information avoidance is to maintain either behavior, emotion-avoiding negative emotion or maintaining positive emotion - or perception about self or environment (Golman, Hagmann, \& Loewenstein, 2017; Sweeny et al., 2010). Besides that, there are situational factors that could either strengthen or weaken the tendency of information avoidance. There are the perception about control over consequences, perception of the existence of resources to deal with information, and the perception of the ease in obtaining information (Afifi \& Weiner, 2004; Howell, Crosier, \& Shepperd, 2014; Sweeny et al., 2010). According to (Sweeny et al., 2010), the higher the uncertainty of individual on estimating their ability to control the consequences after getting information, the higher their need to avoid the information. Furthermore, the decision to avoid information is also motivated by perceived threats when the person notice that his resources are incomparable with the resources needed to deal with the consequences of knowing information (Howell et al., 2014). Finally, difficulties in obtaining, understanding, or accessing information also lead to information avoidance (Afifi \& Weiner, 2004; Sweeny et al., 2010; Wilson, 1997).

The Mastel survey result in 2017, did not mention about the perception about control over the consequences in dealing with hoaxes and perception about the existence of resources in dealing with hoaxes. Results show that Indonesian people do not encounter any difficulties to recognize hoaxes. Most of respondents (66.3\%) perceive that verifying the fact was easy (Mastel, 2017). By identifying the clarity of the news resources and recognizing the oddness of the news, people can easily assume the presence of hoaxes. However, these results also indicate that Indonesian people more rely on other person, mostly that close to them, to clarifying hoaxes, and this could be the reason for unsure feelings about their ability to directly recognizing hoaxes. Unsurprisingly $47.1 \%$ of respondents reported that they forwarded the 
news from the close person before previously verifying the fact.

Information avoidance behaviors in Indonesia still need to be discussed. It is necessary to examine people's tendency to deal with various information, helping them in recognizing hoaxes. As a preliminary study, this study focuses on researching people's tendency to avoid information that can help them in recognizing hoaxes. The main focus is to see the correlation between the tendency of information avoidance with critical skills and perceptions of easiness in obtaining information to recognizing hoaxes (POE). About the survey results from Mastel (2017), we assume that (1) CS have a correlation with information avoidance behavior and (2) POE have a correlation with information avoidance behavior.

\section{METHOD}

Data collection was conducted in June 2018 and used the online questionnaire. Two hundred respondents have completed the questionnaire. Seventeen respondents were excluded because their ages do not meet the criteria. Only 183 were included in this study, 112 are female and 71 are male. Range of participant's ages is between $20-26$ years old $(\mathrm{M}=21.98 ; \mathrm{SD}=1.35)$. Based on demographic data, $33.3 \%$ of respondents live in East Jakarta, 30.6\% in South Jakarta, 25.1\% in West Jakarta, 6.6.\% in Central Jakarta, and $4.4 \%$ in North Jakarta.

In this study, we measured the critical skill that related to digital literacy. We adapted critical skill subscale from Digital Literacy Scale (Rodríguez-de-Dios, Igartua, \& Gonzalez-Vazquez, 2016) to measure it. In the process of scale adaptation, each statement was translated into Bahasa Indonesia. One of the original statements (Identify the author of the information and evaluate their reliability) was separated into two statements in Bahasa Indonesia (I know how to identify the author of an information and I know how to evaluate the credibility of the author) to avoid the confusion of two different verbs (activity) in one statement, namely identify and evaluate. This scale consists of six items, with five points Likert scale $(1=$ strongly disagree, $2=$ disagree, 3 = neutral, $4=$ agree, $5=$ strongly agree). Cronbach alpha was used to estimate the reliability. Two items were dropped, because of the poor inter-item correlations. The dropped items were "I know how to compare different apps in order to choose which one is most reliable and secure" $(r=.348)$ and "If I meet someone online, I know how to check if their profile is real" ( $r=.333)$. The remaining four items have a good level of reliability $(\alpha=.741)$ and internal consistencies $(r=.495-.571)$.

The Information Avoidance Scale (Howell \& Shepperd, 2016) was adapted into Bahasa Indonesia to measure the information avoidance tendencies. This scale has eight items, with six points Likert scale $(0=$ strongly disagree, $1=$ disagree, $2=$ somewhat disagree, $3=$ somewhat agree, $4=$ agree, 5 strongly agree). The original items gave blank space to be filled with the avoidance target, and we use "avoiding the information which indicate that the news that been read is hoax". To check the reliability, we conducted a trial study with 64 Psychology students from BINUS University. Based on the result, two items that have low inter-item correlation were dropped. They were "In my opinion, it is important to know whether or not the news that I read are hoaxes" ( $r=-.0595)$ and "I can think of situations in which I would rather not know whether or not the news that I read are hoaxes" $(r=.332)$. The reliability and the internal correlations of the remaining items are at a good level $(\alpha=.792, r=.441-.712)$.

The measurement for POE was constructed based on the thought of Sweeny et al. (2010), which states that it involved the perception about accessibility and availability to gain the information, also the possibility to comprehend the information. The context of information refers to "whether or not the 
news that been read are hoaxes". In this study, one's ability to comprehend the information is considered as the ability to check and examine the information. Five items were constructed with six points Likert scale $(0=$ strongly disagree, $1=$ disagree, 2 = somewhat disagree, $3=$ somewhat agree, 4 $=$ agree , and $5=$ strongly agree). One item was dropped from the scale (In my opinion, there are several methods to examine, whether the news I have read hoaxes or not) because have a poor inter-item correlation $(r$ $=-.008)$. The scale has a good level of reliability $(\alpha=.751)$ and internal consistency $(r=.405-.643)$.

Table 1.

Estimation of Reliability

\begin{tabular}{lc}
\hline Variabel & $r_{i x}$ \\
\hline
\end{tabular}

Critical ability $(\alpha=.741)$

1. I know how to compare different sources to decide if the information is $\quad .567$ true.

2. I know how to determine if the information I find online is reliable. 495

3. I know how to identify the author of an information. 571

4. I know how to evaluate the credibility of the author.

Information avoidance $(\alpha=.792)$

1. I rather not know, whether or not the news I have read are hoaxes. $\quad .712$

2. I would avoid learning whether or not the news I have read are hoaxes. $\quad .521$

3. Event if it will upset me, I want to know whether or not the news I have $\quad .530$ read are hoaxes. (R)

4. When it comes to hoaxes (whether or not the news I have read are .441 hoaxes), ignorance is bliss. ( $\mathrm{R})$

5. I want to know whether or not the news I have read are hoaxes. (R) 627

6. I want to know whether or not the news I have read are hoaxes, .490 immediately. (R)

\section{Perception about the easiness in getting information $(\alpha=\mathbf{. 7 5 1})$}

1. I will find no difficulties in examining the fact or hoaxes of my news I $\quad .591$ have been reading.

2. For me, the method to examine the news about the fact or hoaxes is easy $\quad .643$ to be done

3. There is nothing preventing me to verify the news I have been reading. $\quad .564$

4. I have idea about the way to verify the news, hoaxes or fact 405

Note. $\mathrm{R}=$ reverse coded

\section{RESULTS AND DISCUSSION}

As mentioned at Table 2, the respondents have a low tendency in information avoidance $(M=1.15 ; S D=.71 ; \operatorname{Min}=.75$; Max = 3). On the other hand, their critical skills are at the average level $(M=3.78 ; S D$ $=.59 ;$ Min $=1.75 ;$ Max $=5)$, means that the respondents have good skills to evaluate the news. The perception of easiness in obtaining information is at the middle level
$(M=3.50 ; S D=.75 ; \operatorname{Min}=.50 ; \operatorname{Max}=5.00)$, means that the respondents perceive that is easy to verify whether or not the news are hoaxes.

The level of critical skills and the perception of easiness indicating a sufficient ability to recognize whether or not the news they read are hoaxes. This result is consistent with the survey results conducted by Mastel (2017), which states that Indonesian people are 
perceiving that verifying the fact was easy. Although, the respondents have a higher confidence about their ability to recognize hoaxes, compared to the survey results found by Mastel (2017). That confidence was shown by respondents' perception that they have good abilities to recognize hoaxes and it is easy to recognize hoaxes.

Table 2.

Descriptive Analysis of Variables

\begin{tabular}{lll}
\hline & M & SD \\
\hline $\begin{array}{l}\text { 1. Critical ability } \\
\text { 2. Information avoidance } \\
\text { behavior }\end{array}$ & 3.78 & .59 \\
$\begin{array}{l}\text { 3. Perception of easiness in } \\
\text { obtaining the information }\end{array}$ & 3.50 & .71 \\
\hline
\end{tabular}

As mentioned at Table 3, critical skills and information avoidance have a significant correlation $(r=-.305 ; p<.01)$, means that the higher the critical skills, the lower the tendency of information avoidance behavior. Also, there is a significant relationship between the perception of easiness in obtaining information and information avoidance $(r=-.217 ; p<.01)$, means that the higher the perception about easiness to obtain the information of hoaxes, the lower is the tendency to avoid the information. These results support both assumptions. However, the correlation are weak.

Table 3.

Correlations between variables

\begin{aligned} & \hline 2 \\ & \hline\end{aligned}

1. Critical ability

2. Information avoidance $-0,305^{*}-$ behavior

3. Perception of easiness in $0,508^{*}$

$\begin{array}{ll}\text { obtaining the information } & 0,217 * \\ \text { Note. } * \mathrm{p}<.01 & \end{array}$

The negative correlation between critical skills and information avoidance supports the result from Pennycook and Rand (2018)), arguing the relationship between individual critical skills and ability to recognize the hoaxes. Good level of critical skills leads to ability in distinguishing hoaxes and facts, and with these skills, individuals tend to examine and identify the hoaxes indicators. Meanwhile, negative correlation between perception about the easiness of getting information and the tendency to avoid information support the thought of Afifi and Weiner (2004), Sweeny et al., (2010), and Wilson, (1997). They describe that the difficulty in obtaining, understanding, and accessing information leads to information avoidance behavior. The more natural the way in getting information is, the more likely people tend to search the information, and therefore the lesser is the need to avoid it.

The low tendency to information avoidance indicating that, like result on Mastel (2017), Indonesian have a need to identifying hoaxes, especially they want to know whether or not the news that they read are hoaxes. This result and its negative correlations with another two variables emphasize that we can use information avoidance as an indicator to see people's level of concern regarding to the truth of a news.

The level of critical skill and the perception of easiness to obtain information in this study also indicate that Indonesian have a strong confidence in recognizing hoaxes. This phenomenon also occurs in other countries. Based on research and survey, either in national or multinational level, the level of concern and the level of confidence in Indonesian people toward hoaxes are similar to Singaporean (Ipsos, 2018), American (Gallup, 2018), Canadian (Canadian Internet Registration Authority, 2018), and European (European Commission, 2018). This fact indicates that people in most countries consider hoaxes as a critical issue, and they already have confidence in identifying hoaxes in cyberspace. This study is also an evidence that Indonesian people have excellent critical skills and perception about easiness in verifying news and therefore enables people to identify hoaxes better by not avoiding the indicators of hoaxes. 
The result form this study gives an alternative solution for the hesitation in recognizing hoaxes. On Mastel (2017), Indonesian people are not sure that they can immediately recognize whether the news that they read were hoaxes. They are aware of hoax indicators and able to verify the fact of news, but they hesitate on that abilities. At least, based on this research, there are two ways that can be done to strengthen the beliefs on Indonesian people ability in recognizing hoaxes. First, internally, by the constant use of critical thinking. Constantly using critical thinking make people get used to identify and analyze each article or news that they read and recognize hoaxes better. Second, technologically, by giving a digital label to hoaxes article. This method would help people to know hoaxes easily, and help them to learn the indicators of hoaxes. This technological method has become a widely discussed research topic on developing either machine language or algorithm in applications or software so that hoaxes can automatically identified (Al-Ash \& Wibowo, 2018; Prasetijo et al., 2017; Pratiwi, Asmara, \& Rahutomo, 2017).

This research only discusses critical skills and perceptions of easiness to obtain information. Although the result represents the confidence in recognizing hoaxes, and this study did not directly address the ability in recognizing hoaxes. Ipsos (2018) states that four out of five Singaporeans believe that they can recognize hoaxes, but $91 \%$ of them failed in identifying hoaxes. It means that the high confidence to recognize hoax does not correlate in the capability of recognizing hoax. In order to get a complete picture of hoax-related behavior, future studies about the ability to avoid hoaxes are necessary to be conducted.

Even though the relationship of critical skills and perception of easiness to obtain information is found in this study, these results do not provide enough evidence in how far critical skills and the perception of easiness are playing a role in information avoidance behavior. It is suggested that this study is only a preliminary study.

\section{CONCLUSION}

The widespread hoaxes in the digital world require each individual to be able to verify and evaluate the information correctly. This study provides an overview of the level of critical skills in young adults in Indonesia, and also their perception about easiness and accessibility in recognizing the hoaxes in Indonesia. Moreover, this study also shows their concern about news containing facts. This concern was demonstrated through the low tendency of avoiding information regarding hoaxes. The low tendency of avoiding behavior is negatively correlated with critical skills and perception about easiness in verifying hoaxes.

\section{ACKNOWLEDGEMENT}

The researcher would like to thank the Bina Nusantara Foundation for providing a grant to conduct this research. Thanks also goes to Musa and Gandhi for helping the data collection.

\section{REFERENCES}

Afifi, W. A., \& Weiner, J. L. (2004). Toward a theory of motivated information management. Communication Theory, 14(2), 167-190. doi:10.1111/j.14682885.2004.tb00310.x

Al-Ash, H. S., \& Wibowo, W. C. (2018). Fake News Identification Characteristics Using Named Entity Recognition and Phrase Detection. Proceeding of 2018 10th International Conference on Information Technology and Electrical Engineering (ICITEE), 12-17. doi:10.1109/ICITEED.2018. 8534898

Allcott, H., \& Gentzkow, M. (2017). Social media and fake news in the 2016 
Election. Journal of Economic Perspectives, 31(2), 211-236. doi:10.1257/jep.31.2.211

Bakir, V., \& McStay, A. (2017). Fake news and the economy of emotions. Digital Journalism, 6(2), 154-175. doi:10.1080/21670811.2017.1345645

Buckingham, D. (2003). Media education and the end of the critical consumer. Harvard Educational Review, 73(3), 309-238.

Buckingham, D. (2015). Defining digital literacy: What do young people need to know about digital media? Nordic Journal of Digital Literacy, 2015(4), 21-34.

Canadian Internet Registration Authority. (2018). Canada's Internet Factbook 2018. Retrieved from: https://cira.ca/facebook/canada'sinternet-facebook-2018

Eshet-Alkali, Y., \& Amichai-Hamburger, Y. (2004). Experiments in digital literacy. CyberPsychology \& Behavior, 7(4), 421-429. doi:10.1089/cpb.2004.7.421

European Commission. (2018). Flash Eurobarometer 464: Fake news and disinformation online. Retrieved from:

http://ec.europa.eu/commfrontoffice/ publicopinion

Fernandez, M., \& Alani, H. (2018). Online misinformation: Challenges and future directions. $W W W^{\prime} 18$ Companion: The 2018 Conference Companion, 595-602. doi: $10.1145 / 3184558.3188730$

Gallup. (2018). American views: Trust, media and democracy. Retrieved from:

https://knightfoundation.org/reports/a merican-views-trust-media-anddemocracy

Golman, R., Hagmann, D., \& Loewenstein, G. (2017). Information avoidance. Journal of Economic Literature, $55(1)$ 96-135. doi: $10.2139 /$ ssrn. 2633226

Hargittai, E. (2005). Survey measures of web-oriented digital literacy. Social Science Computer Review, 23(3), 371-379.

doi:10.1177/0894439305275911

Howell, J. L., Crosier, B. S., \& Shepperd, J. A. (2014). Does lacking threatmanagement resources increase information avoidance? A multisample, multi-method investigation. Journal of Research in Personality, 50(1), 102-109. doi:10.1016/j.jrp.2014.03.003

Howell, J. L., \& Shepperd, J. A. (2016). Establishing an information avoidance scale. Psychological Assessment. doi:10.1037/pas0000315

Ipsos. (2018). Trust and confidence in news sources. Retrieved from: https://www.ipsos.com/en-sg/suscep tibility-singaporeans-towards-fakenews

KBBI Daring. (2016). Retrieved from: https://kbbi.kemdikbud.go.id

Klein, D. O., \& Wueller, J. R. (2017). Fake news: A legal perspective. Journal of Internet Law, 20(10), 5-13.

Lazer, D. M. J., Baum, M. A., Benkler, Y., Berinsky, A. J., Greenhill, K. M., Menczer, F., ... Zittrain, J. L. (2018). The science of fake news. Science, 359(6380), 1094-1096. doi:10.1126/ science.aao2998 
Manalu, S. R., Pradekso, T., \& Setyabudi, D. (2018). Understanding the tendency of media users to consume fake news. Jurnal Ilmu Komunikasi, 15(1), 1-16. doi:10.24002/jik.v15i1.1322

Masyarakat Telematika Indonesia. (2017). Hasil survey Mastel tentang wabah hoax nasional. Retrieved from: https://mastel.id/infografis-hasilsurvey-mastel-tentang-wabah-hoaxnasional/

Pennycook, G., \& Rand, D. G. (2018). Lazy, not biased: Susceptibility to partisan fake news is better explained by lack of reasoning than by motivated reasoning. Cognition, (June), 0-1. doi:10.1016/j. cognition.2018.06.011

Prasetijo, A. B., Isnanto, R. R., Eridani, D., Soetrisno, Y. A. A., Arfan, M., \& Sofwan, A. (2017). Hoax detection system on Indonesian news sites based on text classification using SVM and SGD. Proceedings of 2107 4th International Conference on Information Technology, Computer, and Electrical Engineering (ICITACEE), 45-49.

Pratiwi, I. Y. R., Asmara, R. A., \& Rahutomo, F. (2017). Study of hoax news detection using naive bayes classifier in Indonesian language. Proceedings of International Conference on Information \& Communication Technology and System (ICTS), 73-78.

Rodríguez-de-Dios, I., \& Igartua, J.-J. (2014). Risks of interactive communication: A digital literacy proposal.
Proceedings of the Second International Conference on Technological Ecosystems for Enhancing Multiculturality, 653-657. doi:10.1145/2669711.2669969

Rodríguez-de-Dios, I., Igartua, J.-J., \& Gonzalez-Vazquez, A. (2016). Development and validation of a digital literacy scale for teenagers. In F. J. Garcia-Penalvo (Ed.), Proceedings of the Fourth International Conference on Technological Ecosystems for Enhancing Multiculturality (TEEM'16) (pp. 1067-1073). doi: $10.1145 / 3012430.3012648$

Sirajuddin, Kamil, S. U. R., \& Fachruddin, S. (2017). War 3.0: The Indonesia challenge against hoax, hate speech and social media abuse. Advances in Social Science, Education and Humanities Research (ASSEHR), 143, 88-90.

Sweeny, K., Melnyk, D., Miller, W., \& Shepperd, J. A. (2010). Information avoidance: Who, what, when, and why. Review of General Psychology, 14(4), 340-353. doi:10.1037/a0021288

Tandoc Jr., E. C., Lim, Z. W., \& Ling, R. (2017). Defining "fake news": A typology of scholarly definitions. Digital Journalism, 6(2), 137-153. doi:10.1080/21670811.2017.1360143

Wilson, T. D. (1997). Information behaviour: An interdisciplinary perspective. Information Processing \& Management, 33(4), 551-572. doi:10.1016/s0306-4573(97)00028-9 